\title{
The Flâneur, the Badaud and Empathetic Worker
}

\section{Ekaterina Netchitailova}

\author{
Sheffield Hallam University, Sheffield, United Kingdom, \\ ekaterina.p.netchitailova@student.shu.ac.uk
}

\begin{abstract}
In this paper, based on the development of the 'empathic' badaud in France at the end of the nineteenth and beginning of the twentieth centuries, I draw some parallels with a Facebook user. The experience of Facebook's users is explored through the juxtaposition of two terms: the flâneur (a stroller) and the badaud (gawker), and a third term is proposed, the one of an empathetic worker, by applying critical media/cultural studies. My main argument is that the Facebook user can experience the network at different levels. It is still possible to be the flâneur while being on the network, when the user uses Facebook solely for the purpose of discovery. It is also possible to be the badaud when we log into the network for its sensational purposes, for gossip and mindless entertainment. And finally, the user also works for the corporation, since all interactions, feelings and emotions, are turned by Facebook into profit.
\end{abstract}

Keywords: Flâneur, Badaud, Empathetic worker, Facebook user, Critical Media/Cultural studies, Capitalism, Affective Labour

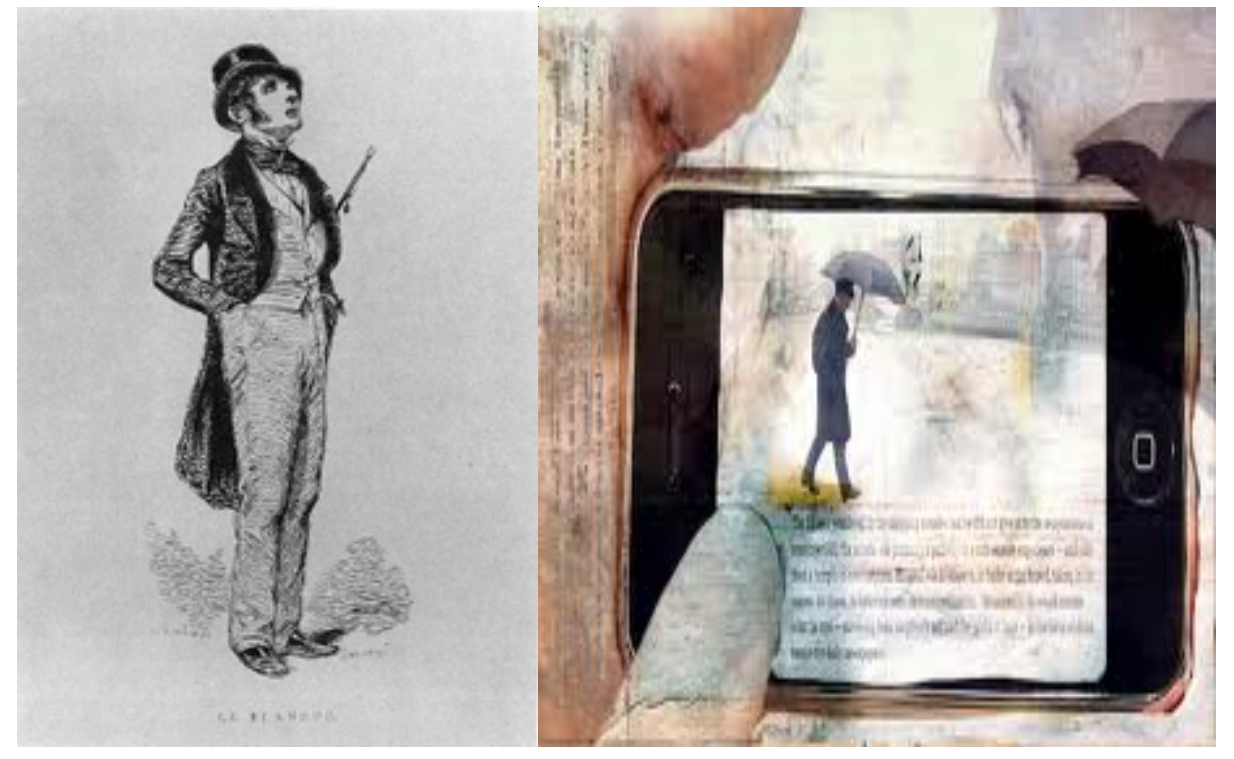

Figure 1: Le Flâneur (Paul Gavarni 1842) and Cyberflâneur (maryannreilly.blogspot.com 2012)

\section{Introduction}

In this article I propose to look at a Facebook user by going back to two definitions in the French language: the flâneur and the badaud.

The original definition of 'le flâneur' is that of a stroller, a lounger. It comes from a literary type from the 19th century Paris. The flâneur was a man of leisure, the explorer of a city, the 
one who would observe the life around him, without necessary taking an active role in it, while still being a part of it. Walter Benjamin (1999) described the flâneur as the essential figure of urban, modern experience. The flâneur was the investigator of modern life. According to Benjamin the flâneur met his demise with the triumph of consumer capitalism. The flâneur became the badaud, where individuality disappears and where the flâneur becomes part of the crowd, losing his creativity and desire for exploration. The badaud was also transformed by the Parisian press into an empathic badaud, a part of the public which cares. In this paper I trace back the development of empathic badaud and analyse how this term can be applied to a Facebook user, which then becomes an empathetic worker. I start by looking at how the Facebook user is looked at in academia at the current moment, then discuss in more details the critical studies of media and information approach and explain how by applying critical media/cultural studies we can also incorporate the dimension of popular culture into the analysis of online social networks, and finally define a term of an empathetic worker by discussing the experiences of the flâneur and the badaud on Facebook and explaining the difference with the term of 'affective labour'.

\section{Facebook and Critical Theory}

Everyday millions of people log into Facebook to conduct sometimes important and sometimes trivial activities. As of September 2012 the network had more than 835,525 users and the number continues to grow (Internet World Stats 2012).

Due to the rapid growth of Facebook and its high popularity, it has become an important topic in academic research. The studies of Facebook can be classed in two distinctive camps: on the one hand, there is research which focusses almost entirely on the user of the network, without taking account of the macro-context, and on the other hand, we have critical media and communication studies, as for example found in Christian Fuchs' work (2009, $2011,2012,2013)$, which look at the phenomenon of online social networks within the context of capitalism.

The studies which look at online social networks without the analysis of socio-political and economic contexts, in which these networks are based, can be called uncritical. Most of them celebrate the potential of these networks and the Internet in general, and point to the participatory and democratic qualities of the medium. Thus, Henry Jenkins, for instance, argues that "the web has become a site of consumer participation" (Jenkins 2006,137) and that blogging and taking part in different Internet forums expand our perspectives, give us chance to be heard and express our opinions and boost our creative potential. Alex Bruns (2007) talks about the rise of produsage which is the "hybrid user/producer role which inextricably interweaves both forms of participation, and that produsage reinforces our collective intelligence, allows everyone to participate in networked culture and can reconfigure democracy as we know it" (Bruns 2007, 27). Clay Shirky (2008) argues that such sites as Flickr, YouTube, MySpace and Facebook create opportunities for public participation, Don Tapscott and Anthony Williams (2006) say that the proliferation of the Internet leads to a new economic democracy, in which everyone has a role and can have their say, while David Gauntlett elaborated on the capacity of social media for 'doing culture' (Gauntlett 2011, 11).

On the other hand, we can also see the re-emergence of critical studies of media and communication which analyse the phenomenon of the Internet within capitalism and point to the commodification of the medium, surveillance and the fact that the usage of the Internet and online social networks is often dictated by big corporations, whose main drive is profit. These studies are radically different from 'critical' cyberculture studies, led by such scholars as David Bell (2001), David Silver (2006), and focus on "issues relating to class, exploitation, and capitalism" (Fuchs 2011, 9). For Christian Fuchs, 'critical' cyberculture studies lack the profound analysis of the society in which the Internet is based, and "therefore an approach that in its postmodern vein is unsuited for explaining the role of the Internet and communications in the current times of capitalistic crisis. The crisis itself evidences the central roles of the capitalist economy in contemporary society and that the critical analysis of capitalism and 
socio-economic class should therefore be the central issue for Critical Internet Studies" (Fuchs 2011, 10).

The current research on online social networks is heavily dominated by these two trends (either celebrating participatory culture or pointing to domination and exploitation in capitalistic societies in which these mediums are used) and is either uncritical and focusses mostly on the user or analyses mostly the macro-context in which the medium is used.

In order to explain such a phenomenon as Facebook the integration of both political economy and cultural studies is needed. Facebook can be seen as a miniature society taking place online. On the one hand, it reflects capitalism through Facebook being a corporation pursuing profit, but on the other hand, people log in there to do their own things, they communicate with friends, upload pictures, create groups and do many other activities which are significant for them and also for many others. Facebook is not only a corporation but also a cultural form, and therefore, on needs a new approach, which Douglas Kellner calls (2009) 'critical media/cultural studies' and which looks at Facebook as both embedded in capitalism, but also a tool that is enjoyed by millions of people on a daily basis and can tell us a lot about such things as friendship, changing notions of privacy, identity and the reflection of the celebrity culture. Critical media/cultural studies can be defined as an approach that "reads, interprets, and critiques its artefacts in the context of the social relations of production, distribution, consumption, and use of which they emerge. The dialectic of text and context requires a critical social theory that articulates the interconnections and intersections between the economic, political, social and cultural dimensions of media culture, thus requiring multiple or trans-disciplinary optics" (Kellner 2009, 20). This approach takes into account the sociopolitical context in which the medium is based, but also reflects upon the cultural aspects of the phenomenon and how it is manifested in the daily lives of its users. Based on this approach, I propose to call a Facebook user an empathetic worker.

\section{The Facebook User as a Prosumer and Part of Affective Labour}

Critical studies of media and communication (Fuchs 2011, 2012, 2013) see the user as being exploited by the Internet and online social networks, where the data on the users is collected, processed, analysed and then sold to advertisers. At this moment this is the most advanced research which sees online social networks as a reflection of informational capitalism, where we are offered a service for free but end up being exploited through the privacy policy of the companies offering these services. On Facebook when we sign up we agree to a very long and ambiguous privacy policy, hardly read by anyone, and which clearly states that all the data can be sold to advertisers.

Alvin Toffler (1980) coined the term prosumer within information society. Axel Burns (2007) applied this term to new media and coined the term produsers - where users become producers of digital knowledge and technology.

As Trebor Scholz (2010) argues, we produce economic value for Facebook mainly in three ways: 1 . providing information for advertisers, 2. providing unpaid services and volunteer work, and 3. providing numerous data for researchers and marketers.

The first one is related to the fact that our mere presence on Facebook provides invaluable information to advertisers. Starting with our birth date and finishing with our likes and dislikes, all this can be processed by advertisers to target their advertisements to users. The third one is in line with the argument of Nigel Thrift (2005) that the current age of capitalism is increasingly knowing and any information we post, in our case Facebook, can be sold to third parties and "transformed into profitable spreadsheets" (Scholz 2010, 245).

The second economic value, providing unpaid services and volunteer work, is especially interesting, as Facebook basically uses the labour of its users for free. Scholz mentions that many Facebook users provide willingly their time and energy for Facebook use. An example is the translation application, where users translate Facebook into different languages totally for free. Roughly ten thousand people participated in the application which allowed Facebook to be read and used in many languages, besides English. However, also providing our data to advertisers and third parties, by simply being on Facebook and having 'fun', also consti- 
tutes working for Facebook and advertisers for free. Users by commenting, uploading pictures and 'liking' pages on Facebook generate revenues for the network, as it then sells their data to advertisers. It can be then argued that users produce surplus value and "engage in the production of user-generated content" (Fuchs 2009, 30).

Users of Facebook also provide data and content for the site, making it more appealing for use, through photos, comments, etc. One of the strategies employed by such corporations as Facebook is to lure the users through the promise of free service, who in turn produce content. This content, in turn, is sold to third-party advertisers.

Maurizo Lazzarato (1996) introduced the term 'immaterial labour', which means "labour that produces the informational and cultural content of the commodity" $(1996,133)$. This term was popularized by Michael Hardt and Antonio Negri who said that immaterial labour is labour "that creates immaterial products, such as knowledge, information, communication, a relationship, or an emotional response" (Hardt and Negri 2004, 108). For them the main purpose of immaterial labour is to create communication, social relations and cooperation. Knowledge produced in this way would be exploited by capital. "The common [...] has become the locus of surplus value. Exploitation is the private appropriation of part or all of the value that has been produced as common" (Fuchs 2011, 299).

As Fuchs explains the Internet is part of the commons because all humans need to communicate in order to exist. But, as he continues, "the actual reality of the Internet is that large parts of it are controlled by corporations and 'immaterial' online labour is exploited and turned into surplus value in the form of the advertising-based Internet prosumer commodity" (Fuchs 2011, 299).

This labour which works in the Internet economy for free can also be called 'knowledge labour' since 'immaterial labour' might mean that there are two substances of the world - matter and mind (Fuchs 2011). Corporations using the knowledge labour lure the users by offering a 'free' access but where users provide content which can be turned into profit through advertisements. "Hence the users are exploited - they produce digital content for free in nonwage labour relationship" (Fuchs 2011, 299).

Capitalism's imperative is to accumulate more capital. In order to achieve this, capitalists either have to prolong the working day (then it is called absolute value production) or to increase the productivity of labour (relative surplus value production) (Fuchs 2011). In the case of relative surplus value production productivity is increased so that more commodities and more surplus value are produced in the same period as previously.

Targeted Internet advertising can be called relative surplus value production (Fuchs 2011, 2013). The advertisements are produced by advertising company's wage workers but also by users of the online social networks, whose content in the profiles and transaction data are used to make advertisements. Users also produce content for free for Facebook itself, and thus, provide unpaid labour, which Fuchs terms also 'play-labour' (Fuchs 2011). Users use such sites as entertainment mainly and usually in their free time. But without realizing it, in their free time they actually continue working for free for numerous Internet sites, by posting comments, updating profiles and by buying and selling things.

Facebook is a typical example of a new service-for free model which saw a rise under informational capitalism. In this way it is part of a new trend where our internet activities are turned into profit by capitalists. The Facebook user is also part of 'affective labour', a term used to reveal labouring practices which "produce collective subjectivities, produce sociality, and ultimately produce society itself" (Hardt 1999, 89). This type of labour is part of immaterial labour discussed above, but has the goal of creating affects and is usually found in health services, the entertainment industry and "the various culture industries" which are "focussed on the creation and manipulation of affects" (Hardt 1999, 95). This labour is "embedded in the moments of human interaction and communication" and its products "are intangible: a feeling of ease, well-being, satisfaction, excitement, passion, even a sense of connectedness or community (Hardt 1999, 96). It is built on human contact where there is "the creation and manipulation of affects" (Hardt 1999, 96).

However, the definition that Hardt and Negri propose deals mostly with aspects of work seen as labour. The authors emphasise that affective labour can happen during leisure time, 
which they see as exploitation mostly. In the age of informational capitalism where work shifted even more into production of knowledge, which involves constant creation of ideas, and often outside working time, according to Hardt and Negri, as a result, people end up working all the time. "When production is aimed at solving a problem, however, or creating an idea or a relationship, work time tends to expand to the entire time of life" (Hardt and Negri 2004, 111). However, my argument is that we should look differently at a Facebook user. Online social networks are a reflection of informational capitalism, where the activities of users are turned into profit, but can we call it labour time, when people logging into Facebook or any other online social network, clearly have fun on it and do not necessary see it as exploitation?

\section{The Facebook User as an Empathetic Worker}

I propose to call the Facebook user an empathetic worker, a definition which takes into account both the fact that the user's activities and feelings are turned into profit by Facebook, but which is not necessary judged by the user as direct exploitation. In their daily lives when people log into Facebook they think of seeing what their friends are doing, comment on status updates, upload pictures and experience all kinds of feelings and emotions that we do when we communicate with friends, relatives or colleagues. I wanted to catch this aspect of interaction on Facebook by defining a Facebook user and situating it within the critical media/culture studies perspective which takes into account both the popular culture aspect and also an economic and political environment. There is invisible exploitation going on while users use Facebook, since the network uses the data of the users for the commercial purposes, but at the same time users have fun on the network and derive numerous benefits from being on the network. There is an interplay going on inside Facebook. Advertisers and Facebook try to catch the trend of interaction and consumption in order to exploit it, while ordinary people who use Facebook simply log in there to do their own thing, sometimes trivial, but sometimes very significant. Culture can never be contained fully, as the example of Facebook demonstrates. We are exploited on it, but we also create there, build relations and play with our identity. Looking at a Facebook user from the critical media/cultural perspective, one shouldn't give one and precise definition to a Facebook user. The Facebook user is exploited, but also has fun and might be doing something on the network which clearly benefits his or others' life. And therefore, I propose to look at the experience of Facebook's users through 3 terms: the flâneur, the badaud and empathetic worker.

The term of empathetic worker catches the exploitative aspect of the network, but doesn't exclude the possibility of looking at time spent on Facebook as leisure time in its original sense.

Marx and Engels (1845/46) distinguished between work and labour. Work is a necessary productive activity which serves to provide the means of subsistence. Humans need to work in order to create food for their survival, for self-fulfilment and as a community building. Labour, on the other hand "is a necessary alienated form of work, in which humans do not control and own means and results of production" (Marx and Engels 1845/46, 4). Work is more general definition. Work is necessary in order to create goods and services. However, under capitalism work is organised in such a way that products of labour belong to the dominant class and therefore, work becomes an alienated labour.

Christian Fuchs and Sebastian Sevignani (2013) look at how work and labour function on Facebook. Through work we create consciousness and language. The activities then on Web 2.0/Web 3.0. which are the activities involving cognition, communication and co-operation are forms of work (Fuchs and Sevignani 2013). Cognition is related to work of the human brain, while communication involves interaction between human groups and co-operation (Fuchs and Sevignani 2013). On Facebook users produce value for themselves which is creative work and value for Facebook, which becomes digital labour. "Facebook's objects of labour are human experiences" (Fuchs and Sevignani 2013, 259). Users while spending their time on Facebook often share intimate moments of their lives with their friends, upload and comment on pictures, chat, have fun or experience moments of sadness and loneliness while 
they are on there. Facebook captures emotional aspects of its users' lives and uses it for profit. Therefore, I call a Facebook user an empathetic worker. An empathetic worker is a user of Facebook who uses Facebook for personal or professional reasons (mostly personal), shares intimate moments of his life on the site, experiences feelings and emotions while communicating with friends and relatives, and where Facebook as a corporation catches this interaction in order to make profit. The user of Facebook is creative when he is on Facebook, because he automatically provides some content for the corporation. But this creativity is channelled into generating revenues for Facebook. I use the term 'work' instead of labour because when users of Facebook log in they do not consider it as work, but think of Facebook as an important part of their lives and where they mostly communicate with friends. Work on Facebook reflects work as a necessary part of being human if we go back to the definition of Marx and Engels, because communication, community-building and friendship are the essential elements of the social aspect of our lives. The user is also empathetic because s/he usually experiences and shares feelings and emotions on the network.

Empathy has a broad definition but usually involves recognising emotions of others, caring for and recognising what other people are feeling, as well as blurring the line between self and other (Hodges and Klein 2001). Affective labour usually involves the aim of achieving something. The oxford dictionary defines affect as having an effect on something and as 'touching feelings of', moving emotionally. ${ }^{1}$ This presupposes some goal, the result of one's actions. Workers involved in affective work, such as in entertainment or services industry, usually try to put their customers at ease, please them, bring them joy so that customers then either buy something or leave a tip. Empathy, however, is a broader and more internal definition. Empathy doesn't need to have any aim, it can remain as an emotion experienced by one person without the aim of moving emotionally someone else. One of the most influential study of empathy by the philosopher Theodor Lipps (1979) looked at empathy as a very complex notion, which included both external manifestation of our feelings, when we respond to anger or joy experienced by another, as well as internal, which could remain invisible inside an individual and would become the phenomenon of 'internal imitation' (Lipps 1979, Stueber 2013). Empathy can be both external and internal mirror of our emotions and feelings and empathy is more appropriate in the analysis of Facebook, as users do not necessary always react or want to achieve something through their comments and statuses updates. The whole emotional aspect when users simply read something without reacting in any visible form (such as commenting), while feeling some emotions internally, is also empathy. The Facebook user can stare at the screen of the computer without doing anything and still remain an empathetic worker, since he spent time on creating the account, filling in the profile and building a network of friends. The user doesn't need to do anything, apart from experiencing an emotion. Empathy also involves "an observer's reacting emotionally because he perceives that another is experiencing or is about to experience an emotion" (Stotland 1969, 272).

All this can be drawn back to the identity stages of George Herbert Mead (1967), and which can be seen in how users of Facebook interact on the site. George Herbert Mead said that the self is established through communication. The individual for Mead was a product of society, of social interaction. For Mead, we could only see ourselves in relation to other people. We are first an object of others, and then we conceive the perspective of other people through language and communication we become an object to ourselves. In the case of Facebook, we can look at our profiles as objects of our friends, but through communication on Facebook via pictures, status updates, profile updating, we take the perspective of others on us to communicate to the audience. On Facebook we often project what others might think of us through statuses updates, comments, etc.

Mead saw social interaction and identity through 'Me' and 'I'. 'Me' related to the social self, while 'I' is the response to 'Me'. When people update their status on Facebook or communicate what is on their mind, they present the 'me', based on socialization they have already

\footnotetext{
${ }^{1}$ http://www.oxforddictionaries.com/definition/english/affect
} 
experienced. The 'I' maintains the Facebook profile by selecting 'me' to project to the world and ourselves.

For Mead social existence and communicative identity is a three-step process through which the self is developed: language, play and game (1967).

- Language: through language or communication we take on 'the role of the other' which allows us to respond to our own gestures (form an opinion about ourselves) in terms of the symbolised attitudes of others.

- Play: through play we take on roles of other people and pretend to be the other people in order to correspond to expectations of significant others.

- Game: through game we internalise the roles of all others and form our own identity through 'rules of the game' (knowing how to behave in certain situations).

The three activities of Mead through which the self is developed can be applied to Facebook as well: First of all, people become aware of intentions of other individuals through their actions and gestures (Ellis 2010). For instance, when we upload a picture on Facebook or put a status update there, we communicate something about us to others. These others, by looking at our update or a picture, form an opinion about us and our intentions. By commenting on pictures or links friends 'project' our social identity back to us. Second, we communicate our identity to others. By putting a certain picture on Facebook, we try to project a certain image and in general know the response in advance. By uploading a picture from our holidays we expect others to react to it in a certain way, by commenting for instance, what a great holiday we had. The profile picture also shows something about ourselves. It is the 'I' which chooses 'Me'. By putting a picture of myself with a cat on Facebook I try to show that I like this animal and that cats play an important role in my life. Here, we also engage in impression management. We try to build a certain image of ourselves, but this image is built on how others perceive us in our social reality. These are the second and third stages of identity creation at the same time since we try to impress others and also engage in the rules of the game, such as uploading pictures on Facebook that an increasing number of people do, and commenting under pictures in a certain way.

And finally, the picture we upload means something to us, it means something for our social identity. "...this picture means something to the individual who is negotiating their personal identity among the available social identities. Identity, as it emerges in the mind of an individual, cannot be separated from social processes and interactions" (Ellis 2010, 39). When I upload a picture of myself with a cat, I already know that I do like cats in real life and that they are important in my life.

Thus, on Facebook we engage in building our identity and it allows for self-discovery, as building a Facebook profile is in a way a reflective act. While building the profile we ask questions about ourselves: what do I want to project? How will others perceive me? What shall I include in the profile and what is most important for me in terms of how others perceive me? This involves the creation and maintenance of profiles, but also interaction of users through status updates, the uploading of pictures, participation in groups, etc. Users of Facebook log in on Facebook to see what their friends and relatives are doing, and experience feelings and emotions when they see the news from their friends. If someone feels lonely and puts this fact on the status update, we usually try to cheer this person up through a reply. Thus, we directly show that we care, but also other people can see that we care and this contributes to the building of our own identity. We participate on the site empathetically, by reading status updates of our friends, by sharing moments of our lives, by commenting on the moments of lives of others. All this, however, is used by Facebook to create personalised advertisements. The Facebook user who logs on Facebook to communicate works for Facebook at the same time.

At the same time, as mentioned previously, the user can also experience fun while being on the network, without feeling that $s /$ he is being exploited. Facebook is not only a business corporation pursuing profit, but also a site where people log in for a multitude of reasons. Looking at the Facebook user only from the point of view of exploitation misses the social 
aspect of the network. And therefore, it would be insufficient to call a Facebook user by using one single term which would mostly catch the exploitative and commercial aspect of Facebook. I propose to look at a Facebook user by going back to two terms in the French language: the flâneur and the badaud. By using these two terms we can also build another picture of empathetic worker, based on making of empathic observer by the French Press in the $19^{\text {th }}$ and beginning of the $20^{\text {th }}$ centuries.

\section{The Facebook User as the Flâneur and the Badaud}

Gregory Shaya in his article 'The Flâneur, the Badaud and the Making of a Mass Public in France...' traces the making of an 'empathic observer' by the French press in 1960-1910 (2004). His description of how a French stroller, the flâneur became a badaud, a consumer rather than observer of life and then an empathic observer or 'valorised badaud', can be applied to a Facebook user as well, which through the fact that the user also works for the corporation, becomes an empathetic worker.

The flâneur, a term coming from the French language, means a stroller. It is derived from the French noun 'un flâneur' which is based on the French verb 'flâner' with the translation to stroll. The flâneur became an interest in literary and philosophic circles in the $19^{\text {th }}$ century in France and became associated with a leisure figure of an intellectual on a walk. It was Charles Baudelaire who gave the term its additional meaning, where the flâneur became a 'stroller with a purpose', where the purpose was mostly intellectual, in order to learn something new and interesting about the city. Thus, Baudelaire defined the flâneur as someone who walks around the city in order to experience it and learn something from it (Baudelaire 1964).

The term was popularised by Walter Benjamin (2002) who made out of flâneur a subject of academic interest. The flâneur was a literary type in France, a man of leisure, who would walk across the streets of Paris and observe life around him. The flâneur was an explorer of life, a detective of the city. He was in the crowd but also outside of it, refusing to take an active part in any consumption, and instead walking around solely for 'the gastronomy of the eye' as Balzac described the experience of the flânerie (Shaya 2004, 47). However, with the rise of the consumption which happened after the reconstruction of the Parisian boulevard under Baron Haussmann, giving way for more shops and creating a "visual pleasure for an eager public" the flâneur has become a badaud, where he mixes with the crowd and his individuality disappears (Shaya 2004, 43). As Walter Benjamin argued, the flâneur became someone who is turned into profit. He became the badaud, the gawker - someone who stares at the objects without reflection and takes part in the society of consumption without wondering about its substance. The online free dictionary defines the term as "a person given to idle observation of everything, with wonder or astonishment..." It is a person who wants gossip and sensations.

This was also the time of the rise of the commercial mass press, which Jürgen Habermas (1991) blamed for the decline of the public sphere, when a "culture-debating public" transformed into a "culture consuming public", and where the flâneur gave way to badaud, a spectator of 'fait divers'. The badaud, however, having often a negative connotation in scholarly articles is not always a simple passive spectator, as can be seen in the description of modern life provided by Guy Debord (1967). While the badaud is certainly in search of the sensational, he is also taking part in the surroundings, and this was exploited by the mass press in 1860-1910 in France to make out of badaud an "empathic observer", a part of the public that was defined by "sensations, passions, and curiosity" (Shaya 2004, 42).

As Shaya traces this development, it was a deliberate construction of a new type of observer and reader, to attract more curiosity to sensational facts but also "as a mechanism of solidarity of an era of social conflict and fractured identities" (Shaya 2004, 44) Describing a crime or an accident with pictures of people who happened to be in the proximity, was a way to assemble the community around a cause and boost participation in public life. Witnesses on the pictures emerged as not simply badauds, gasping with an open mouth at the scene,

\footnotetext{
${ }^{2}$ http://www.thefreedictionary.com/Badaud
} 
but as sympathetic and emotional observers who cared. This, of course, led later to the fact that the press' capturing of the popularity of 'fait divers' has become even more sensationalistic, creating more of what Debord (1967) called a society of the spectacle..

Given this interplay between the flâneur, the badaud and 'empathic observer', the concept of a valorised badaud can be applied to Facebook as well. Facebook is often used as distraction, as an alternative to boredom. Many people keep the Facebook page open to occasionally 'check the noise', or gossip provided willingly by their friends on the network. The fact that gossip is provided intentionally is worth being looked upon. Facebook as never before provides a perfect stage for dramatic performance for its participants, and relates perfectly well to the observation of Erving Goffman that "the world, in truth, is a wedding" (Goffman 1959, 45).

On Facebook people mainly 'front', they intentionally try to create a certain impression through their pictures, status updates, comments, etc. Facebook provides a perfect stage for instant validation, where members have immediate access to an audience for their performance.

It is not unusual for participants on Facebook to exaggerate their lives, make it more sensational and more interesting. Many put only their best pictures on Facebook, post status updates about beach holidays, parties and other events that could make one's life more appealing. Vejby and Wittkower looked at this phenomenon in the book 'Facebook and Philosophy' and argue that the mass media leads to the passive outlook at life. "Just as, in the society of the spectacle, we have little choice but to adopt received market-integrated representations of life (buying things), liberty (the freedom to buy whatever we want) and the pursuit of happiness (buying more expensive things), so too does the mass media present us with a series of images which we can only passively accept or reject - but not change, or reply to" (Vejby and Wittkower 2010, 99). This is similar to the experience of the badaud in France in the early twentieth century, when the badaud was looking after sensational experiences, provided by the press and crime scenes. However, this badaud, as already explained, wasn't a simple gawker, he was also sympathetic and caring, taking part in the surroundings in order to gain more experience.

The sensationalisation on Facebook reflects in general a culture that "privileges the momentary, the visual and the sensational over the enduring, the written, and the rational" (Turner 2004, 4). Facebook reflects the tendency in our society to be obsessed with celebrity culture. It is a general fascination with the image and simulation which perhaps makes Facebook so popular. On Facebook we are all badauds to a certain extent, watching the intimate details of our friends' lives and deriving a sense of pleasure from it.

Facebook provides both social contact and relaxation and corresponds to our desire for the sensational. Here, our own lives can become sensational and we become the image makers of our own life. Not only do we watch the lives of our friends, which relates to our innate desire for gossip, but we can also present our lives as we see it fit.

According to Debord we live in a society where "life is presented as an immense accumulation of spectacles. Everything that was directly lived has receded into a representation" (Debord 1967, 7) The spectacle for Debord "is a social relation between people that is mediated by images" (Debord 1967, 7).

For Debord the authentic life has been replaced by representation. "Everything that was directly lived has receded into a representation" (Debord 1967, 7). For Debord the importance of life has been reduced into having - we are driven by consumption and accumulation, and having has receded into merely appearing. Happiness can be achieved through a new car, a new house or fashion, but this is not true happiness, it is just an illusion of happiness. The current life has become the pursuit of commodities where "people's activity becomes less and less active and more and more contemplative" (Debord 1967, 34).

For Debord people became passive viewers of life instead of its active makers and mass media is to blame for it. We are dominated by contemplation of useless programmes about celebrities, where fame or pursuit of fame or having a new gadget has become the main goal of life for many people. Genuine relationships have been replaced by consumption of friendship where meeting with friends is accompanied by shopping or consumption. Instead of do- 
ing sport we watch sport on the TV, where sport itself became the commodity, with sport stars becoming celebrities and new idols. Instead of singing for pleasure, singing has become the pursuit of fame and fortune as demonstrated by popularity of such programs as $\mathrm{X}$ Factor and American Idol. Instead of living our lives actively and allowing for critical thought, we simply spectate.

In this respect Facebook can be seen as another spectacle. On Facebook we 'spectate' our friends instead of meeting them in real life. We are bombarded with advertisements linked to our profiles and posts, and here our life is becoming a mere commodity, where even in profiles we are driven to fill them in according to capitalist logic. Our profiles are dominated by the things we consume, watch and buy.

But another way to look at it is to acknowledge this consumption as an art of living everyday life and as creativity. By looking at Facebook as simply a spectacle or as useless consumption misses the point of what popular culture is and that people derive pleasure and meaning from things which can seem pretty trivial but are significant for them. The Facebook user is also an empathic badaud, caring for the lives of others and going on Facebook not only for entertainment but also in order to create, to share and to experience feelings and emotions which are not linked to the desire of the sensational.

As John Fiske argues: "Popular culture is made at the interface between the cultural resources provided by capitalism and everyday life [...]. Popular discrimination is thus quite different from the aesthetic discrimination valued so highly by the bourgeoisie and institutionalized so effectively in the critical industry. 'Quality' - a word beloved of the bourgeoisie because it universalizes the class specificity of its own art forms and cultural tastes - is irrelevant here. Aesthetic judgements are antipopular - they deny the multiplicity of readings and the multiplicity of functions that the same text can perform as it is moved through different allegiances within the social order [...] Aesthetics requires the critic-priest to control the meanings and responses to the text, and thus requires formal educational processes by which people are taught how to appreciate 'great art' [...] Aesthetics is naked cultural hegemony, and popular discrimination properly rejects it" (Fiske 1989, 130).

The point that Fiske makes is that people are controlled through work and continue being controlled outside work by what the dominant order judges as useful and 'correct' so that the worker is ready to go back to work the next day and not question the existing order. Fiske gives the example of pleasure and how the capitalist system tries to control pleasure by providing its own meanings which are supposed to be followed. Facebook is often talked down as a waste of time and as useless consumption because many people tend to use it either at work or instead of doing something more 'useful'. Facebook is often relegated to something which is dangerous and addictive, exactly because it is also a means of control over patterns of consumption and tastes. However, the fact that Facebook is also a perfect product of the capitalist system does not prevent some users from using it against capitalism. There are many instances where users create protests and rallies on Facebook itself, and actually have 'fun' with the fact that it is impossible to control everything which happens on the network. On the other hand, would Facebook as corporation allow any serious rally against the existing order on its network? Something which would be seen as a real danger to the status quo? Probably not.

But while Facebook as a corporation would be unlikely to allow anything which could create problems for its status-quo, is there also a way on the network for the flânerie, a French word derived from the flâneur and which is associated with the activities of the flâneur, such as discovery, intellectual curiosity, looking at something without the aim of buying?

The term the flâneur has been a subject of renewed academic interest in the mid-1990s with several academics creating new, derived terms from the word. We had the 'cyberflâneur' (Goldate 1997), 'Virtual flâneur' (Featherstone 1998), 'online flâneur', and even postmodern flâneur' (Hartmann 2004). All these authors who propose the new terms for the original flâneur argued that the experience of the flânerie acquired a new meaning on the Internet. All these new concepts offered to look at the flânerie as a new phenomenon. If the old flâneur was investigating without taking part in his surroundings, then on the internet the cyberflâneur also has the possibility to create, and thus, he also takes part in what he is observing. 
The culmination of looking at the experience of the cyberflâneur optimistically came with the publication of the article by Evgeny Morozov in New York Times in 2012 in which he declared that the cyberflâneur is dead (Morozov 2012). To explain the death of the phenomenon Morozov goes back to Paris in the $19^{\text {th }}$ century and reminds us how the flâneur was killed then, through the reconstruction of the city to create more shops. "Such rationalization of city life," he writes, "drove flâneurs underground forcing some of them into a sort of "internal flânerie..." (Morozov 2012). According to the author, any sort of flânerie on the internet reached the same level, "transcending its original playful identity, it's no longer a place for strolling," as Morozov describes the Internet, "it's a place for getting things done" (Morozov 2012).

However, looking at the flâneur both from over-optimistic point of view, as was done with the term in the mid-1990s or from over-pessimistic point of view as did Morozov, misses the rich meaning of the original term. The term flâneur has been discussed and is still discussed in the literary circles in France, and its original meaning is much more complex than is usually attributed to it. Then Walter Benjamin was describing how the flâneur was turned into profit by the department stores, he also mentions that a state of 'in-betweeness' is possible, when the flâneur is attracted to the newness but doesn't necessary buy. "The flâneur still stands on the threshold - of the metropolis as of the middle class. Neither has him in its power yet (Benjamin 2002, 10). As Edmunt White argues in his book where he talks about the experience of the flâneur, it was still possible to remain the flâneur even after the reconstruction of Paris. "Even rebuilt and outfitted with all those identical trees...benches and kiosks, more than any other city Paris is still constructed to tempt someone out for an aimless saunter, to walk on just another hundred yards- and then another" (White 2008, 38).

And therefore, my argument is that we should go back to the original term of the flâneur without re-inventing the wheel. The term is rich and complex enough to apply it in any setting or experience. As it was still possible to stay the flâneur among endless shops, it is still also possible to be the flâneur on the Internet and also on Facebook. We need new terms to reflect on how any Internet experience can be turned into profit, but we don't need new terms to describe all human experiences on the net. What to make out of academics who 'stroll' Facebook out of intellectual curiosity? What to make out of idle observers who simply want to learn something new? What to make out of all these people who discover something new on Facebook every day, such as some new music, an important piece of news, or a book to read?

And this is why the Facebook user is a multitude of things at the same time. When we log in we don't necessary think about Facebook as a corporation, we log in because Facebook is a part of our daily lives, our friends are on there, and we want to see what these friends are doing and share what we are doing in return. The Facebook user is also a flâneur when he or she wants to look at what is happening on Facebook out of curiosity and in order to enrich his or her life. The Facebook user is also a badaud, when he or she logs in to Facebook for the desire of gossip, and finally, the Facebook user is also an empathetic worker. While Shaya in his article calls the badaud an 'empathic' badaud, I consider the term empathetic more appropriate for the Facebook user. Both terms are almost similar, but there is a slight nuance of difference. Empathic is a feeling experienced by an empath mostly in order to show that one cares. Empathetic, however, incorporates an additional dimension, when one not only experiences emotions towards others, but also through these emotions experiences feelings towards oneself. It is recognising what others try to tell us on Facebook, but also sharing our own feelings in return, and building our identity as a result. These feelings and emotions are captured by Facebook to make a profit, and therefore, the empathetic user also becomes an empathetic worker.

\section{Conclusion}

In this paper I analysed the Facebook user by using critical media/cultural studies. Critical media/cultural studies acknowledge both the socio-political context in which a medium is based (capitalism), as well as the cultural dimensions of the medium and how it affects peo- 
ple in their daily lives. The Facebook user is a part of 'immaterial labour', he is a prosumer and also play-worker and affective worker, if we take into account the fact that Facebook as a corporation collects data on us and sells it to advertisers while we communicate with our friends and participate on the site 'socially'. At the same time, the Facebook user experiences the network on a different level in his daily life. When we log in the network we want to have fun, we desire some gossip, we also want to see what our friends are doing and share what is happening in our lives with them. We do not consider that we are exploited when we spend our time on Facebook, but usually consider that we derive numerous benefits from using Facebook. Therefore, I propose to call the Facebook user an empathetic worker, someone who experiences emotions while using the medium, while these emotions are then turned into a profit.

\section{References}

Babe, Robert. 2009. Cultural Studies and Political Economy: Toward a New Integration. Lanham: Lexington Books.

Baudelaire, Charles. 1964. The Painter of Modern Life. New York: Da Capo Press.

Benjamin, Walter. 2002. The Arcades Project. Cambridge, MA: First Harvard University Press.

Bell, David. 2001. An Introduction to Cybercultures. London and New York: Routledge.

Bruns, Alex. 2007. Produsage, Generation C, and Their Effects on the Democratic Process. Media in Transition 5, 27-29 April.

Debord, Guy. 1992. Society of The Spectacle. London: Rebel Press.

Ellis, Katie. 2010. Be Who You Want to Be: The Philosophy of Facebook and the Construction of Identity. Screen Education 58.

Featherstone, Mike. 1998. Virtual Flâneur. Urban Studies 35: 909-925.

Fiske, John. 1989. Understanding Popular Culture. London and New York: Routledge.

Fuchs, Christian. 2009. Information and Communication Technologies and Society. A Contribution to the Critique of the Political Economy of the Internet. European Journal of Communication 24 (1): 69-87.

Fuchs, Christian. 2011. An Alternative View of Privacy on Facebook. Information 2: 140-165.

Fuchs, Christian. 2011. Web 2.0, Prosumption, and Surveillance. Surveillance \& Society 8 (3): 288309.

Fuchs, Christian. 2011. What Does it Mean to Study the Internet Critically? Paper presented at the 7th International Critical Management Studies Conference. University of Naples Federico II, Naples, Italy. 12th 2011.

Fuchs, Christian. 2012. Dallas Smythe Today - The Audience Commodity, the Digital Labour Debate, Marxist Political Economy and Critical Theory. Prolegomena to a Digital Labour Theory of Value. TripleC: Communication, Capitalism \& Critique 10(2): 692-740.

Fuchs, Christian and Sebastian Sevignani. 2013. What is Digital Labour? What is Digital Work? What's their Difference? And Why Do These Questions Matter for Understanding Social Media? Triple C 11(2): 237-293.

Gauntlett, David. 2011. Making is Connecting: The Social Meaning of Creativity, from DIY and Knitting to Youtube and Web 2.0. Cambridge: Policy.

Goldate, Steven. 1997. The Cyberflâneur. Art Monthly.

Goffman, Erving. 1959. The Presentation of Self in Everyday Life. New York: Ancor.

Habermas, Jürgen. 1991. The Structural Transformation of the Public Sphere: An Inquiry into a Category of Bourgeois Society (Studies in Contemporary German Thought). Cambridge, MA: The MIT Press.

Hardt, Michael. 1999. Affective Labour. Boundary 2:26: 2.

Hardt, Michael and Negri, Antonio. 2004. Multitude: War and Democracy in the Age of Empire. New York: Penguin.

Hodges, Sara and Klein, Kristi. 2001. Regulating the Costs of Empathy: The Price of Being Human. Journal of Socio-Economics 30: 437-452.

Internet World Stats. 2012. Facebook Users in the World. Accessed December 15, 2013. http://www.internetworldstats.com/facebook.htm

Jenkins, Henri. 2006. Convergence Culture: Where Old and New Media Collide. New York: New York University Press. 
Kellner, Douglas. 2009. Towards Critical Media/ Cultural Studies. In Media/ Cultural Studies: Critical Approaches, edited by Rhonda Hammer and Douglas Kellner. Bern: Peter Lang.

Lazzarato, Maurizo. 1996. Immaterial Labour. In Radical Thought in Italy, edited by Paolo Virno and Michael Hardt. Minneapolis, MN: University of Minnesota Press.

Lipps, Theodor. 1969. Empathy, Inner Imitation and Sense-Feelings. In A Modern Book of Esthetics: An Anthology, edited by Melvin Rader. New York: Holt, Rinehart and Winston.

Marx, Karl and Engels, Friedrich. 1845/46. The German Ideology. Amherst, NY: Prometheus Books.

Mead, George. 1967. Mind, Self, \& Society: From the Standpoint of a Social Behaviorist. Edited by Charles Morris. Chicago: University of Chicago Press.

Morozov, Evgeny. 2012. The Death of the Cyberflâneur. New York Times. Accessed December 3 , 2013. http://www.nytimes.com/2012/02/05/opinion/sunday/the-death-of-thecyberflaneur.html?pagewanted=all\&_r=1\&

Shaya, Gregory. 2004. The Flaneur, the Badaud, and the Making of a Mass Public in France, circa 1860-1910. The American Historical Review 109 (1): 41-77.

Shirky, Clay. 2008. Here Comes Everybody: The Power of Organizing without Organizations. London: Penguin Press.

Scholz, Trebor. 2010. Facebook as Playground and Factory. In Facebook and Philosophy, edited by D.E. Wittkower. Chicago and La Salle: Open Court.

Stotland, Ezra. 1969. Exploratory Investigations of Empathy. In Advances in Experimental Social Psychology (Vol 4), edited by Leonard Berkowitz. New York and London: Academic Press, 271-314.

Stueber, Karsten. 2013. Empathy, The Stanford Encyclopedia of Philosophy (Summer 2013 Edition), edited by Edward N. Zalta. Accessed December 1. http://plato.stanford.edu/archives/sum2013/entries/empathy

Tapscott, Don and Williams, Anthony. 2007. Wikinomics: How Mass Collaboration Changes Everything. New York: Penguin.

Thrift, Nigel. 2005. Knowing Capitalism. Thousand Oaks: Sage Publications.

Toffler, Alvin. 1980. The Third Wave. New York: Bentam.

Turner, Graeme. 2004. Understanding Celebrity. Thousand Oaks: Sage Publications.

Vejby, Rune and Wittkower, Dylan. 2010. Spectacle 2.0? In Facebook and Philosophy, edited by D.E. Wittkower. Chicago and La Salle: Open Court.

White, Edmund. 2008. The Flaneur: A Stroll Through the Paradoxes of Paris. London: Bloomsbury Publishing.

\section{About the Author}

Ekaterina Netchitailova

is a Doctor of Philosophy. Her thesis focussed on Facebook by using critical media/cultural studies and where Facebook was analysed both in the context of capitalism and also as a part of popular culture. 